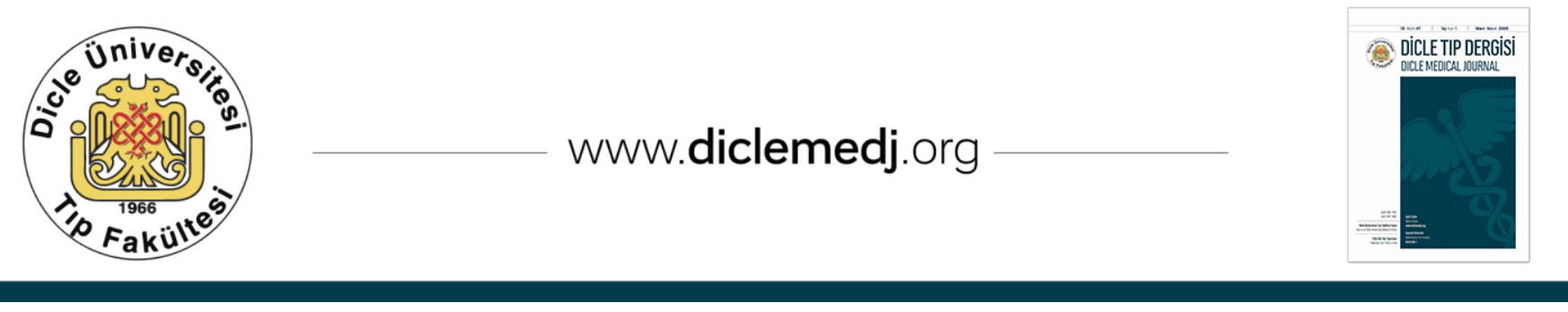

Case Report / Olgu Sunumu

\title{
A Case Of Vena Cava Superior Syndrome With Lymphoma
}

\author{
Lale Sertçelik $^{1}$ iD, Fatma Armağan Hazar ${ }^{1}$ iD, Mine Demir $^{1}$ iD , Ipek Erdem ${ }^{1}$ iD, Aysun Kosif ${ }^{1}$ iD \\ 1 Health Sciences University Istanbul Sureyyapasa Chest Disease and Thorasic Surgery Traning and Research Hospital, İstanbul, Turkey
}

Received: 26.07.2019; Revised: 30.09.2019; Accepted: 22.10.2019

\begin{abstract}
Vena cava superior syndrome (VCSS) defines the deterioration in blood circulation as a result of an obstruction in vena cava superior (VCS) and the resulting clinical condition. It might develop due to various reasons including malign and benign ones.

Because of swelling on the face and neck, 38 year-old woman was undergone thoracic computed tomography. Pleural effusion was observed in right hemithorax and a mass applying pressure on the vena cava superior on the middle mediastinum. Pet-CT was taken; prevascular lymphadenopathies with SUDmax: 21.1 were observed. The frozen result of mediastinoscopy was reported to be necrosis. Thoracotomy was implemented; the pathologic formation thought to be thrombus in the lumen of vena cava superior was excised. At the end of pathological examination, this mass was reported to be unclassified b-cell lymphoma having the characteristics of Burkitt's and large-cell lymphoma. The patient was given chemotherapy. The remission was achieved.

In our case, the reason for VCSS was intravascular thrombus-shaped large B-cell lymphoma. This case was presented because it is a rare reason for VCSS.
\end{abstract}

Keywords: Vena cava superior syndrome, large B-cell lymphoma, thrombus, vena cava superior

DOI: $10.5798 /$ dicletip. 706153

Yazışma Adresi: Lale Sertçelik, Süreyyapaşa Gögüs Hastalıkları ve Göğüs Cerrahisi Eğitim Araştırma Hastanesi C blok 7. servis Maltepe/ İstanbul, Turkey e-mail: lalesertcelik@gmail.com 


\section{Lenfoma Tanısı Alan Bir Vena Cava Superior Sendromu Olgusu}

\section{Öz}

Vena cava superior sendromu(VCSS) , vena cava superiorun (VCS) obstrüksiyonu sonucu kan akımında bozulma ve ortaya çıkan klinik tabloyu tanımlar. Malign ve benign birçok nedene bağlı ortaya çıkabilir.

38 yaşında kadın hastada yüz ve boyunda şişlik nedeniyle toraks bilgisayarlı tomografisi çekildi. Sağ hemitoraksta plevral efüzyon ve orta mediastende vena cava superiora baskı yapan kitle görüldü. Pet-ct çekildi, sud max: 21,1 olan prevasküler lenfadenopatiler saptandı. Mediastinoskopinin frozen sonucu nekroz olarak raporlandı. Torakotomi yapıldı, vena cava superiorun lümeninde trombüs olduğu düşünülen patolojik oluşum eksize edildi. Patoloji sonucu burkit ve büyük hücreli lenfoma özellikleri taşıyan sınıflandırılamayan B hücreli lenfoma olarak raporlandı. Hastaya KT tedavisi verildi. Remisyon sağlandı.

Vakamızda VCSS'un nedeni trombüs görünümlü intravasküler büyük B hücreli lenfomadır. VCSS'un nadir görülen bir nedeni olması sebebi ile sunmak istedik.

Anahtar kelimeler: Vena cava superior sedromu, Büyük B hüreli lenfoma, trombüs, vena cava superior

\section{INTRODUCTION}

Vena cava superior syndrome (VCSS) defines the deterioration in blood circulation as a result of an obstruction in vena cava superior (VCS) and the resulting clinical condition. One of the reasons for VCSS is the lymphomas. The patients may apply with the complaints of coughing, difficulty in breathing, swallowing difficulty, swelling and/or faintness in neck, face, and upper extremities, and enlargement in neck veins ${ }^{1}$.

Intravascular B-cell lymphoma ((IVBCL) is a type of non-Hodgkin lymphoma that has extranodal localization and bad prognosis. They develop as a result of the proliferation of intravascular lymphocytes. According to the classification accepted by World Health Organization, the intravascular large B-cell lymphoma (IVBCL) is a subgroup of diffused large B-cell lymphoma (DLBCL) ${ }^{2,3}$.

The malign lymphocyte cells are rarely involved in small, medium and capillary veins. They might cause lymph node and ectopic invasion ${ }^{2,3}$.

Here, it was aimed to represent a case of VCSS that has developed from a large vascular structure such as VCS and had no extravascular involvement.

\section{CASE PRESENTATION}

38 year-old female patient applied to our hospital with the complaints of swelling on face and neck at intervals for 8 months. Based on the preliminary diagnosis of angioneurotic edema, the skin prick test was performed. The result was negative. The oral methyl prednisolone treatment was started. The complaints of patient decreased but, after discontinuing the medication, the complaints started again. Thinking that it is an allergic reaction, the patient applied to our clinic. There were edema on the face, swelling on the veins, and difficulty in breathing. At the end of physical examination, the body temperature was $36.5 \mathrm{C}$, heart rate was $62 / \mathrm{min}$, TA was $100 / 70 \mathrm{mmHg}$, and 02 saturation was $98 \%$ (at the room temperature). During the physical examination, swelling and edema was observed on the face, enlargement in the neck veins, telangiectasia and venous distention in upper right part of thorax, and mastitis and decrease in respiration sounds in right bottom zone. It was determined that the patient has used fluoxetine tablet upon the diagnosis of depression, besides smoking 15 packages per year (active smoker). In family history, it was determined that her father has died of leukemia. PA lung graph was taken; pleural effusion was observed on right and 
enlargement on the medial mediastinum. (Figure 1)

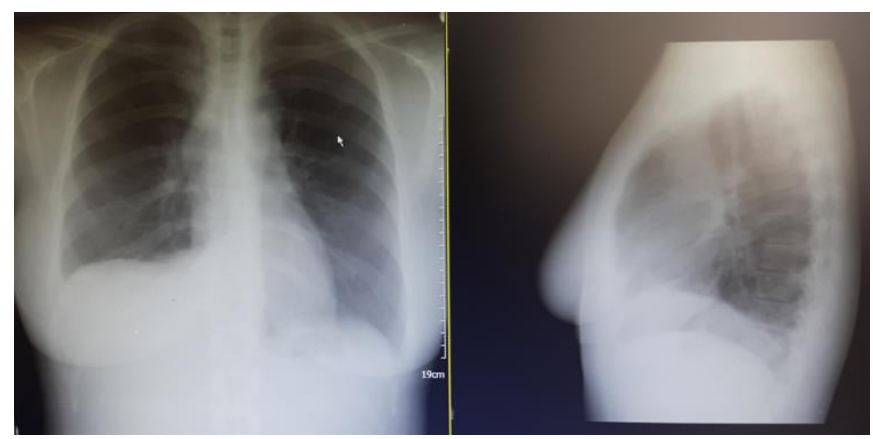

Figure 1. Chest X-Ray

The patient was undergone thoracic computed tomography. Pleural effusion was observed on the right zone and a mass applying pressure on vena cava superior in upper mediastinum, and the patient was hospitalized. (Figure 2,3,4)

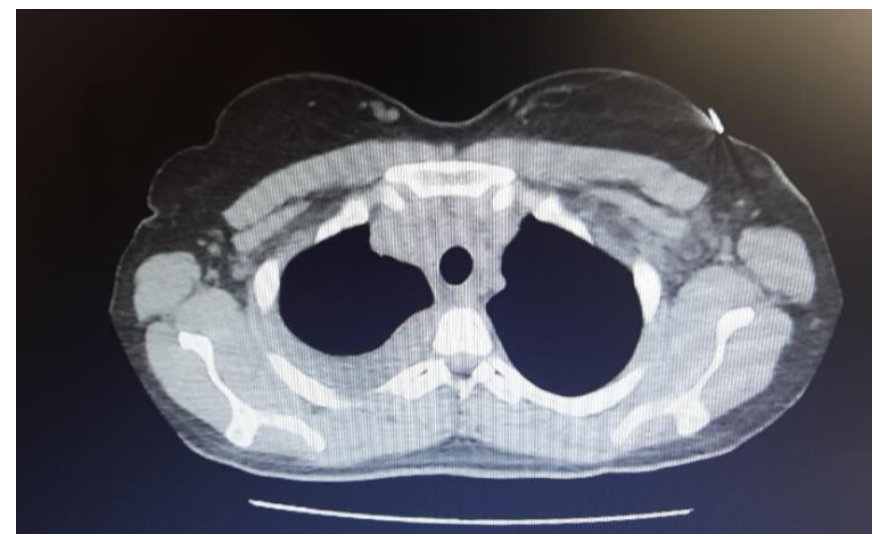

Figure 2. Thorax CT image 1

No characteristic was found in biochemical parameters. Mild anemia (Hb: $10.7 \mathrm{mg} / \mathrm{dl}$ ) was observed in hemogram. Thoracentesis was performed, and exudated pleural effusion was observed. Lymphocytes and mesothelial cells were observed in pathology. The result of pleural fluid AFB(acit fast bacilli) was found to be negative. No proliferation was detected in pleural fluid cultures. In the ultrasound of neck, several lymph nodes, which were obliterating the hilus and short axis of the largest of which was measured to be $5 \mathrm{~mm}$, were observed, and most of them were in bilateral supraclavicular zone and right inferior jugular zone.

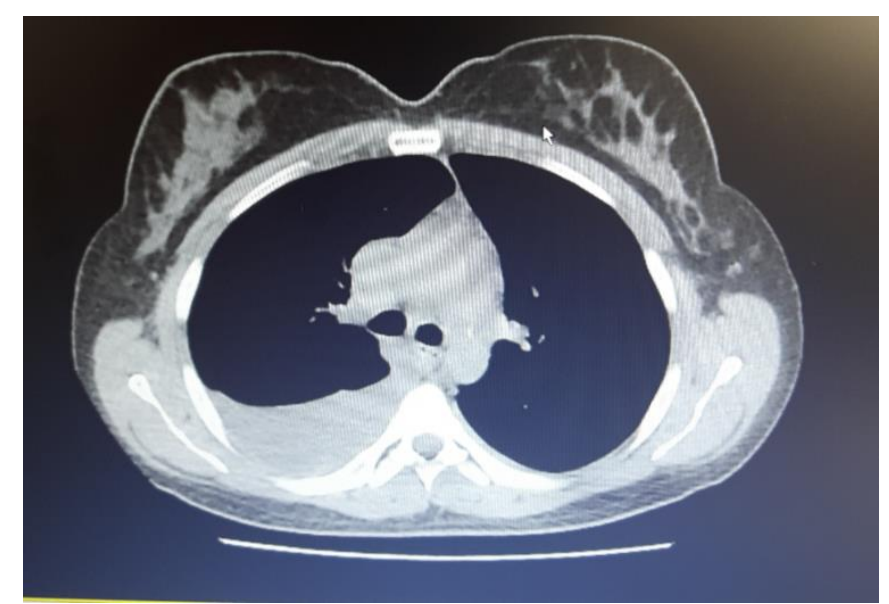

Figure 3. Thorax CT image 2

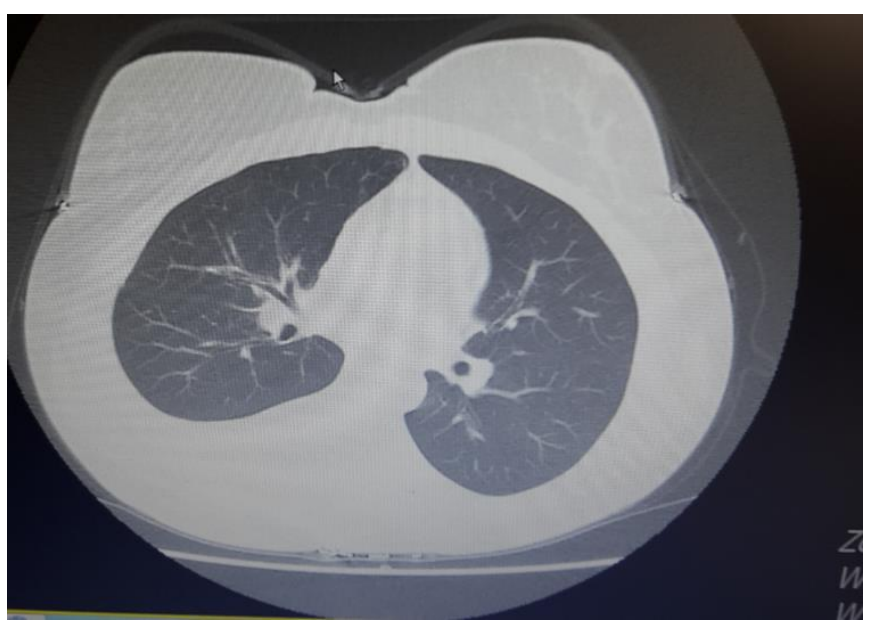

Figure 4. Thorax CT image 3

Abdominal ultrasound was normal. The patient was undergone fiber-optic bronchoscopy and no endobronchial lesion was observed. No endobronchial ultrasonography (EBUS) was performed since the criteria were not met. Because the lymph glands couldn't be palpated, the lymph node excision couldn't be performed. The patient was referred to thoracic surgery consultation for mediastinoscopy. The patient was undergone PET-CT; 5.4R and prevascular conglomerated $30 \mathrm{~mm}$ lymphadenopathy (SUVMAX: 21.1) were detected. (Figure 5) 


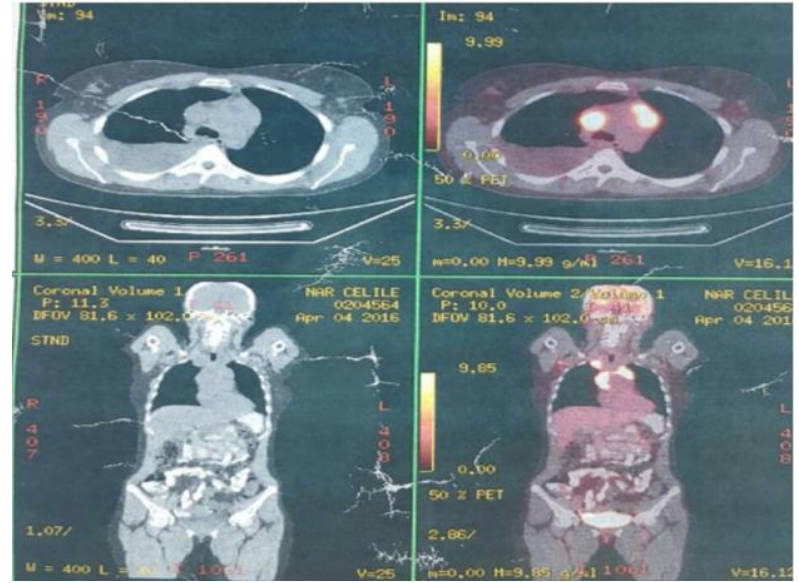

Figure 5. PET-CT image

The lymph nodes were sampled in mediastinoscopy. A necrosis was observed. The patient was undergone thoracotomy operation. (Figure 6)

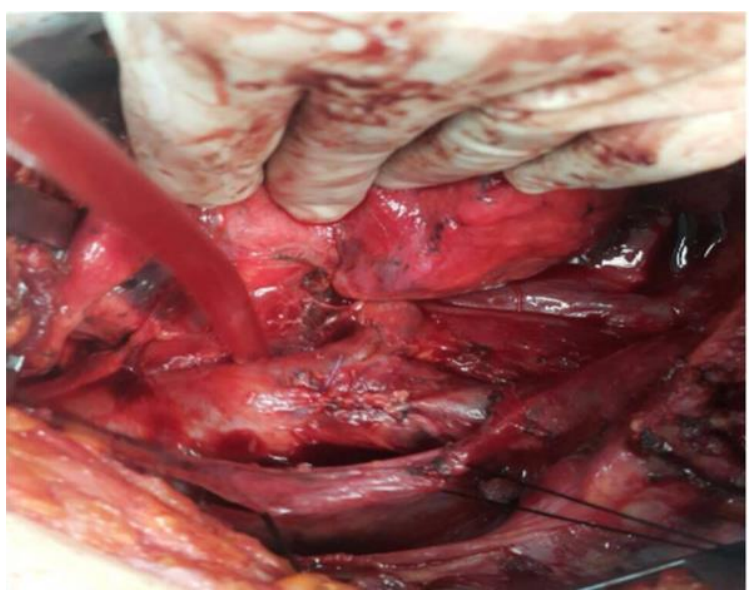

Figure 6. Postop. vena cava superior

In exploration of right thoracotomy, a lesion thought to be thrombus in VCS was detected. The sample was taken from lymph node number 4R. (figure 7)

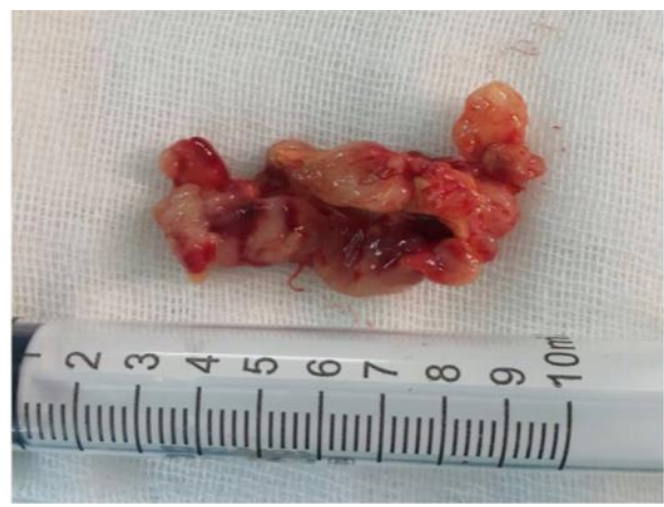

Figure 7. Lymphoid tissue extracted from the vena cava superior

The frozen result was reported to be necrosis. In immunohistochemical analysis in pathology, the lymph node $4 \mathrm{R}$ was diagnosed for reactive hyperplasia, whereas the lesion thought to be anthracosis and thrombus was diagnosed for large B-cell lymphoma. LCA+,CD20+,CD79a +CD3, and CD5 mature T lymphocytes showed $(+)$ immunoreactivity. PANCK (PANCK is a kind of cytokeratin stain which used for immunohistochemical studies.) was negative. The pathology preparations of patient referred to another center for consultation was reported to be unclassified B-cell lymphoma infiltration having the characteristics of soft tissue (paraffin bulk consultation of the material taken from VCS and defined as thrombus) Burkitt's and large cell lymphoma. The chemotherapy was started for the patient, who was discharged on 7th postoperative day. No recurrence was observed during the follow-up period after the treatment.

\section{DISCUSSION}

Vena cava superior syndrome develops due to the following reasons.

\section{Compression; malign and benign lesions}

2. Invasion; malign or benign lesions

3. Thrombosis: hypercoagulability (malignancy and polycythemia), intimal damage (venous pathways) and stasis (external pressure)

4. Construction; Mediastinal fibrosis 4 .

Intra-thoracic malignity cases are responsible for $60-85 \%$ of VCSS cases. $60 \%$ of VCSS cases are observed to be undiagnosed malignity cases $^{4,5}$. The most frequent reason is the nonsmall cell lung cancer with the frequency of $50 \%$, followed by small cell lung cancer with $25 \%$ and non-Hodgkin lymphoma. Lung cancer and non-Hodgkin lymphoma constitute approx. $95 \%$ of all the malign cases contributing to 
VCSS. VCSS develops up to $4 \%$ of non-Hodgkin lymphoma 5 .

Here, it was aimed to represent a case that developed from a large vein such as VCS, is presented with VCSS, has the characteristics of Burkitt's and large cell lymphoma but was diagnosed for unclassified B-cell lymphoma.

A significant portion of these cases are observed in forms of non-Hodgkin lymphoma and its subtypes. The diffused B-cell lymphoma was classified into subtypes by WHO. One of the subtypes is intravascular large B-cell lymphoma. It develops as a result of the proliferation of malign lymphocytes. The intravascular large B-cell lymphoma is a rarelyseen subtype of diffused B-cell lymphoma. The highest incidence was found to be $60 \%$ in large B-cell lymphoma. The mediastinal large B-cell lymphoma constitutes $7 \%$ of all the diffused large-cell lymphomas, it causes sclerosis, and it is aggressive and rare. It is characterized with the presence of large B-cells only in lumen of small veins and especially in capillaries of different organs. The lymph node involvement is rare ${ }^{4,5}$. But, in the present case, the large vein involvement was observed rather than the involvement of small veins. The diffused largecell and lymphoblastic lymphoma are the subtypes of NHL that causes VCAA. Among the patients with intravascular lymphoma, the primary mechanism of VCAA might be the intravascular obstruction ${ }^{3}$. In the present case, the pathology result of thrombus-like bulk taken from VCS during the operation was reported to be B-cell lymphoma ${ }^{4,5}$.

It was aimed to report our case since it is a rare reason of VCSS that is frequently observed in clinical practice and should be immediately identified. It should be kept in mind that the malignity cases seeming like intravascular thrombus may be seen.
Informed Voluntary Consent Form: Informed volunteer consent form was taken from the patient of the case.

Decloration of conclift interest: The authors declare that thay have non conclict of interest.

Finansal disclosure: No financial support was received.

\section{REFERENCES}

1. Balcı AE, Bedirhan MA, Elbeyli L, ve ark. Mediyasten Hastalıkları ve Cerrahisi,1. Baskı, Ankara, Türkiye Solunum Araştırmaları Derneği, 2015; 185-94.

2. Menon MP, Piitaluga S, Jaffe ES. The histological and biological spectrum of diffuse large B cell lymhoma the WHO classification. Cancer J. 2012 september; 18: 411- 20.

3. K Shimada, T Kinoshita, T Naoe, S Nakamura. Presentation and managment of intravasküler B-cell lymhoma. Lancet Oncol. 2009; 10: 895902.

4. Yıldızeli B. Vena Cava Superior Sendromu ve Cerrahisi, doi: 10.5152/tcb.2011.24.

5. Lepper ML, Ott SR, Hoppe H, et al. Superior vena cava syndrome in thoracic malignancies. Respiratory care. May 2011; 56: 653-7. 